\title{
Etika Bisnis Dan Inovasi Produk Makanan Dan Minuman UMKM Di Kecamatan Semampir Surabaya
}

\author{
Yesa Cahayaning Ramadhani*1, Suhermin², Budiyanto ${ }^{3}$, Anang Subardjo \\ 1,2,3,4Program Studi Manajemen, Fakultas Ekonomi, Sekolah Tinggi Ilmu Ekonomi Indonesia (STIESIA) Surabaya \\ *e-mail: yesacahayaning@stiesia.ac.id ${ }^{1}$ suhermin@stiesia.ac.id ${ }^{2}$ ․ budiyanto@stiesia.ac.id ${ }^{3}$,
} anangsubardjo@stiesia.ac.id ${ }^{4}$

\begin{abstract}
The Covid-19 pandemic has had an adverse impact on the sustainability of Indonesia's economic life, especially for Small, Micro and Medium Enterprises (MSMEs). The strategy of MSME actors in dealing with the Covid-19 pandemic situation can allegedly be done through online product marketing. Based on the identification of the previous problem, the Covid-19 pandemic has caused MSME turnover to decline. Because usually these products from MSMEs are marketed to customers at meetings organized by the surrounding community, innovation means an idea, product, information technology that can be used. MSME actors make interesting flyers about their products to be distributed to various business social media so that they can be known by a wide audience. Amondeys Cake and Adirasa Cake have tried to develop themselves through this online marketing. However, beverage SMEs still need creative efforts to produce unique and interesting products.
\end{abstract}

Keywords: Business Ethics, Innovation and Technology

\begin{abstract}
Abstrak
Pandemi Covid-19 memberikan dampak yang tidak baik pada keberlangsungan kehidupan ekonomi Indonesia, khususnya bagi pelaku Usaha Kecil, Mikro dan Menengah (UMKM). Strategi pelaku UMKM dalam menghadapi situasi pandemi Covid-19 diduga dapat dilakukan melalui pemasaran produk secara Online. Berdasarkan identifikasi masalah sebelumnya adalah bahwa pandemi covid-19 ini menyebabkan omset UMKM menurun. Karena biasanya produk-produk dari UMKM ini dipasarkan kepada pelanggan pada pertemuan-pertemuan yang diselenggarakan oleh lingkungan masyarakat sekitar, maka diperlukan inovasi berarti suatu ide, produk, informasi teknologi yang dapat digunakan. Para pelaku UMKM membuat flyer yang menarik tentang produknya untuk disebarkan kepada berbagai media sosial bisnis agar dapat diketahui oleh khalayak luas. Amondeys Cake dan Adirasa Cake telah berupaya mengembangkan dirinya melalui marketing Online ini. Namun UMKM minuman masih perlu upaya kreativitas untuk menghasilkan produk yang unik dan menarik.
\end{abstract}

Kata kunci: Etika Bisnis, Inovasi, dan Teknologi

\section{PENDAHULUAN}

Penyebaran virus Covid-19 yang bermula di kota Wuhan, China pada bulan Desember 2020 telah menjadi sebuah Pandemi yang menyebar hampir keseluruh negara di dunia. Tidak terkecuali di negara Indonesia yang mulai menyebar di sekitar bulan Maret 2020. Dengan adanya pandemi tersebut, pemerintah serta masyarakat Indonesia mengalami shock atau keterkejutan dikarenakan dampak dari pandemi tersebut sangatlah masif. Tidak hanya berdampak serius pada kesehatan (kematian), namun juga berdampak pada perekenomian dan sosial di masyarakat Indonesia (Wiguna et al., 2021).

Pemerintah Provinsi Jawa Timur akhirnya memutuskan untuk melaksanakan Pembatasan Sosial Berskala Besar (PSBB) di wilayah Kota Surabaya Raya, Kabupaten Sidoarjo dan Kabupaten Gresik. Adapun dampak dari penerapan PSBB ini sangatlah signifikan. Masyarakat diwajibkan untuk tidak keluar rumah jika tidak ada kepentingan yang mendesak. Bisnis pun juga mulai menyesuaikan dengan kebijakan dari pemerintah provinsi Jawa Timur tersebut. Sebagai contoh, mall memperlakukan protap untuk dapat masuk ke mall dengan mencuci tangan, pengukuran suhu badan dan penyemprotan disinfektan. Kemudian selama PSBB berlangsung, jam operasional mall menjadi jam 12.00 hingga jam 19.00. Dari pemberlakuan PSBB tersebut, 
secara langsung memberikan dampak kelesuan di bidang ekonomi. Masyarakat menunda untuk membeli barang atau kebutuhan sekunder dan tersier. Masyarakat lebih berhemat untuk pemenuhan kebutuhan premier mereka. Dalam kenyataannya UMKM dapat bertahan dalam menghadapi berbagai kebijakan. Keberadaan UMKM di Indonesia sangatlah penting karena selain dapat menambah pendapatan perkapita masyarakat, UMKM juga dapat mengurangi jumlah pengangguran di Indonesia (Atsar \& Fadlian, 2021).

Pandemi Covid-19 memberikan pengaruh pada keberlangsungan kehidupan ekonomi Indonesia, khususnya bagi pelaku Usaha Kecil, Mikro dan Menengah (UMKM). Jumlah UMKM di Indonesia sebesar 62,9 juta, dari jumlah tersebut $97 \%$ menyerap tenaga kerja dan $89 \%$ di antaranya pada sektor mikro dan berhasil mengkontribusikan sebesar $60 \%$ produk domestik bruto (PDB) ekonomi nasional. Berdasarkan data sebanyak 163.713 pelaku UMKM pada sektor makanan dan minuman terkena dampak pandemi Covid-19, dimana 56\% pelaku UMKM mengalami penurunan penjualan, $22 \%$ pada aspek pembiayaan, $15 \%$ pada aspek distribusi barang, dan 4\% mengalami kesulitan mendapatkan bahan baku mentah dan $75 \%$ mengalami dampak penurunan penjualan (Amri, 2020; Arifudin, Damayanti Rusmana, Tanjung, \& Wahrudin, 2020; Soetjipto, 2020; Thaha, 2020)

Hasil data dari survei penelitian tersebut memberikan gambaran kendala dan peluang penyelesaian masalah bagi pelaku UMKM pada situasi pandemi dan dapat berpengaruh dalam penurunan omzet yang disebabkan oleh daya beli konsumen menurun, sehingga 33\% pelaku UMKM memilih menghentikan produksi, 19\% menghabiskan persediaan barang yang dikembalikan, 8\% melakukan produksi ketika ada pesanan, dan 27\% membuka jual-beli dengan protokol kesehatan yang ketat. Usaha pelaku UMKM melakukan strategi dalam situasi pandemi, yaitu 38\% menggunakan pemasaran melalui media sosial, 35\% menggunakan promosi berbayar secara Online, $13 \%$ menitipkan produk secara konvensional dan $6 \%$ tetap membuka tempat jualan (Soetjipto, 2020)

Strategi pelaku UMKM dalam situasi pandemi Covid-19 adalah melalui pemasaran produk dan secara Online sebagai peluang yang sangat bisa dimanfaatkan untuk perbaikan kualitas produk, penambahan pelayanan konsumen, dan memaksimalkan jaringan pemasaran kepada pelanggan. tetapi disisi lain banyak pelaku UMKM belum memahami cara pemasaran produk secara digital, mulai dari pemfotoan, perancangan iklan, hingga publikasi produk di platform digital. Selain itu, pasar Online melonggarkan pelaku UMKM dalam membuka tempat pemasaran, sehingga tidak terbebani uang sewa tempat. Dampak lain dari pemasaran online akan penghematan luar biasa pada sektor produksi, distribusi, dan pemasaran konvensional serta mengurangi jumlah tenaga kerja yang dibutuhkan pada saat produksi hingga proses distribusi (Hardilawati, 2020). Permasalahan pada mitra berkenaan dengan bagaimana membuat informasi berbasis video, karena hal ini sangat membutuhkan kreatifitas seseorang dengan alur pemahaman yang berbeda beda dalam ilmu video editing (Costaner, Guntoro, \& Lisnawita, 2021). Hal ini berarti pemanfaatan digital marketing mempermudah pelaku usaha untuk berinteraksi langsung dengan pelanggan, sehingga memotong jalur komunikasi antara perusahaan atau pelaku usaha dan pelanggan yang ada sebelumnya, melihat keterlibatan konsumen secara real time serta memungkinkan menyajikan konten yang sesuai dengan preferensi pelanggan (Normawati, Ike Wardani, \& Widayani, 2020).

Dengan belum berakhirnya pandemi covid-19, maka perlu dilakukan pendampingan lanjutan bagi para pelaku UKM di Kecamatan Semampir Kota Surabaya. Dimana pendampingan tahap pertama telah dilakukan di tahun 2020 lalu dengan fokus utama saat itu adalah mengindentifikasi permasalahan yang dihadapi oleh para pelaku UKM tersebut. Untuk pendampingan lanjutan ini, pelaku UKM diberikan pelatihan usaha dengan produk yang masih dibutuhkan di era pandemic covid-19 yaitu Produk Makanan yang memenuhi hygiene dan dan tersaji menarik yang diarahkan pada Pemasaran dan Penjualan secara Online. UMKM harus dapat mengikuti perkembangan zaman, di era yang menuntut berbagai 
perubahan UMKM harus mampu beradaptasi dengan perubahan. Perkembangan dalam dunia usaha di Indonesia saat ini yang semakin cepat dan pesat berakibat juga pada perubahan budaya (Arifudin et al., 2020).

\section{METODE}

Metode pelaksaanaan pengabdian masyarakat pada saat ini tetap sama dengan dengan metode pelaksanaan pengabdian masyarakat lalu. Dikarenakan masih adanya pandemi Covid 19, maka pelaksanaan tidak dapat dilakukan dengan metode tatap muka secara langsung di Balai RW Kecamatan Semampir Kota Surabaya, namun melalui metode daring (Zoom meeting). Adapun tahapan metode pelaksanaan adalah sebagai berikut:

1. Konfirmasi kesanggupan untuk evaluasi dan monitoring kepada UKM Kecamatan Semampir Kota Surabaya dengan metode daring.

2. Melakukan analisis situasi dan permasalahan yang dihadapi oleh UKM Kecamatan Semampir Kota Surabaya.

3. Melakukan evaluasi atas pelatihan yang diberikan sebelumnya.

4. Pendampingan lanjutan dilaksanakan dengan cara memberikan bimbingan teknis secara daring kepada pelaku UKM Kecamatan Semampir, yang mencakup:

a. Cara pembuatan makanan yang memenuhi hiygiene dan tampilan menarik karena akan dipasarkan dan dijual secara Online

b. Eksplorasi potensi dan keunggulan yang dimiliki UKM.

\section{HASIL DAN PEMBAHASAN}

Berdasarkan identifikasi masalah sebelumnya adalah bahwa pandemi covid-19 ini menyebabkan omset UMKM menurun. Karena biasanya produk-produk dari UMKM ini dipasarkan kepada pelanggan pada pertemuan-pertemuan yang diselenggarakan oleh lingkungan masyarakat sekitar. Oleh karena itu sebagai keberlanjutan dari kegiatan sebelumnya, maka pengabdian masyarakat ini akan memonitoring hal-hal yang telah dilakukan oleh para UMKM sekaligus memberikan pemahaman kepada pelaku UMKM tentang pentingnya aliterasi digital dan pemasaran digital. UMKM berperan penting dalam perekonomian Indonesia yaitu kedudukannya sebagai pemeran utama dalam kegiatan ekonomi di berbagai sektor, yaitu: penyedia lapangan kerja yang terbesar dalam pengembangan kegiatan ekonomi lokal dan pemberdayaan masyarakat; pencipta pasar baru dan sumber inovasi antara lain pengembangan ide, produk, informasi teknologi; serta sumbangannya dalam menjaga neraca pembayaran melalui kegiatan ekspor untuk mendorong terjadinya perubahan-perubahan di segala aspek kehidupan masyarakat demi terwujudnya perbaikan mutu setiap individu dan seluruh warga masyarakat yang bersangkutan (Arifudin et al., 2020; Fitriati, Hidayah, \& Maspiyanti, 2021).

Bodeyz Cake milik ibu Camelia telah membuat flyer dan media sosial dalam pemasaranya, dan beliau sudah menggunakan aplikasi toko dalam hal pemasarannya. 


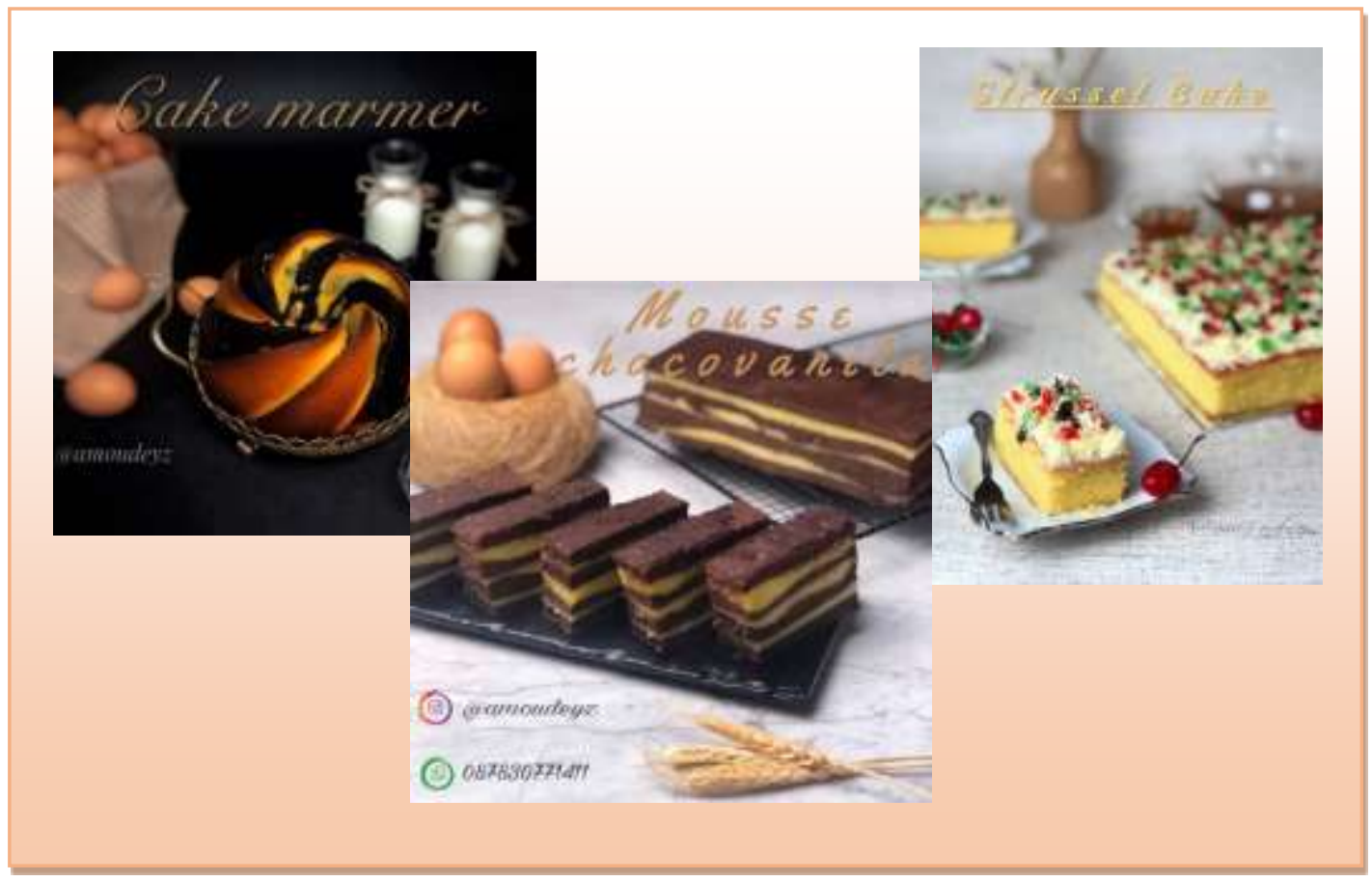

Gambar 1. Hasil kemajuan Amoundeyz Cake

Sedangkan Adirasa Cake miliki linu Aditya Hasan masih menggunakan whatsapp bisnis dalam hal pemasarannya dan belum membuat flyer yang menarik pelanggan. Demikian pula UMKM dalam hal minuman belum memiliki kreativitas dalam membuat flyer ataupun kemasan yang menarik, sehingga masih terkesan tradisional. Adanya perubahan aktivitas yang awalnya dilakukan secara konvensional dan interaksi secara tradisional, manusia bekerja lebih fleksibel dan terkoneksi tanpa batas di semua profesi dan kelompok masyarakat di belahan dunia. Digitalisasi juga mengganti banyak hal, termasuk pengembangan kesejahteraan karena mampu mengakses berbagai sumber informasi tanpa batas dan menjadikan media untuk memajukan kesejahteraan dan kemandirian (Ismail, Ulat, Gunaisah, Muhfizar, \& Poltak, 2021)
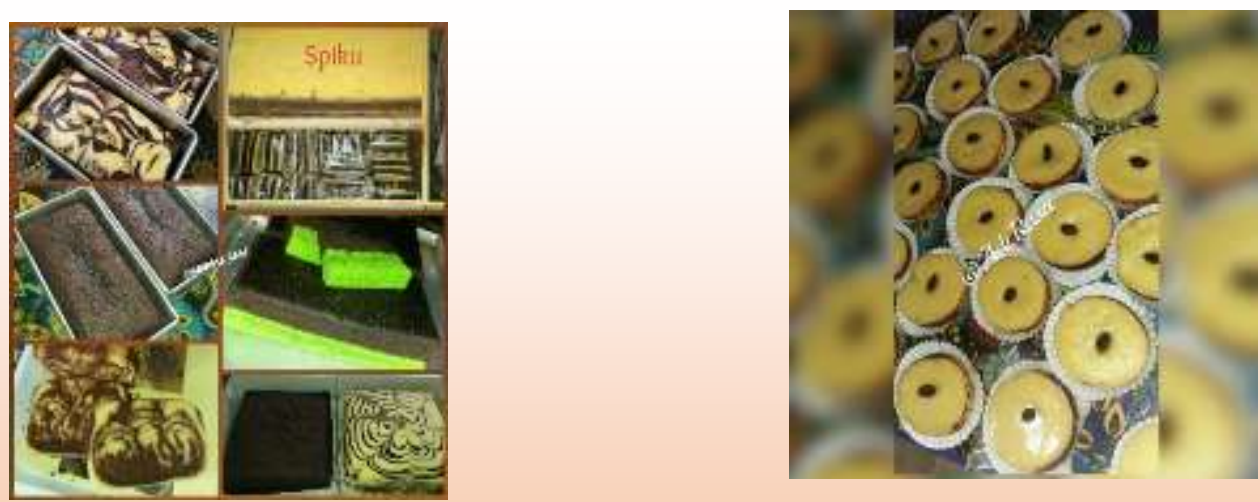
Demikian pula UMKM dalam hal minuman belum memiliki kreativitas dalam membuat flyer ataupun kemasan yang menarik, sehingga masih terkesan tradisional.

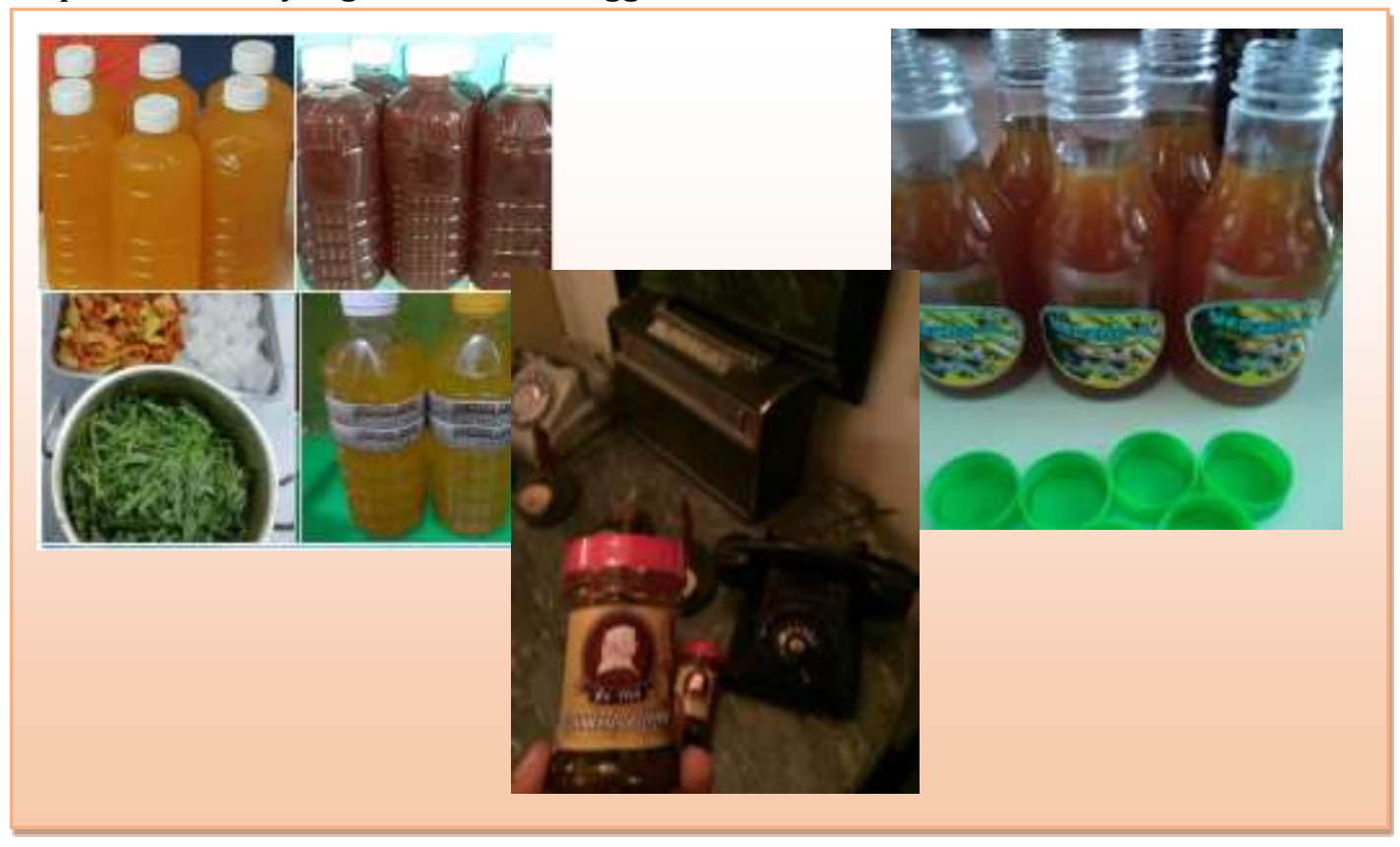

Gambar 3. Minuman Tradisional Sinom

Untuk UMKM minuman masih perlu adanya upaya untuk menyesuaikan diri pada transformasi digital. Meskipun produk minuman adalah minuman tradisional, namun tidak menutup kemungkinan untuk tetap dapat menggunakan pemasaran digital, sehingga diperlukan keterlibataan pelanggan yang telah melakukan transaksi berbelanja produk pada media sosial juga dapat mengundang mereka untuk melakukan pembelian kembali. Kegiatan promosi menjadi faktor penentu dalam meningkatkan jumlah penjualan bagi seluruh jenis usaha. Salah satu cara yang cukup efektif dalam menarik minat pelanggan adalah melakukan pemasaran berbasis online atau yang lebih dikenal dengan sebutan digital marketing.

Pengabdian masyarakat ini dilakukan pada 10 UMKM terpilih dari Kecamatan Semampir Kota Surabaya UMKM yang datang pada kegiatan tercatat ada 6 UMKM dengan berbagai masalah yang ada. Literasi Digital menjadikan ide menggunakan media secara efektif dan tempat informasi yang relevan pada saat ini sehingga diperbincangkan. Media yang dimaksud tentunya adalah pemanfaatan Internet sebagai salah satu media yang sangat erat kaitannya dengan kehidupan manusia.

Pendayagunaan platform digital sebagai peran untuk menopang aktivitas masyarakat Indonesia dalam kegiatan bisnis. Sejumlah pelaku usaha di Indonesia masih belum sadar terhadap teknologi, khususnya pelaku usaha mikro kecil atau biasa disebut UMKM. Selain literasi digital, hal yang harus diajarkan oleh pelaku UMKM yaitu pemasaran digital. Pemanfaatan platform digital menjadi penting dalam menopang kegiatan masyarakat Indonesia salah satunya adalah kegiatan bisnis, karena pada prinsipnya teknologi bertujuan menyediakan kemudahan dari berbagai segi kehidupan, baik dalam bekerja, berkomunikasi bahkan memecahkan permasalahan yang ada di masyarakat (Rahman \& Nurdian, 2021)

Pemasaran digital dapat memanfaatkan media sosial yang ada seperti facebook, instagram bisnis, whatsapp bisnis, dan lain-lain. Beberapa UMKM di Kecamatan semampir sudah memanfaatkan platform media sosial ini meskipun belum maksimal. Meskipun dengan menggunakan media sosial, namun dalam hal pemasarannya masih menggunakan dari mulut ke mulut. Sedangkan dalam penasaran digital lebih ditekankan pada testimoni pelanggan yang diposting pada media sosial tersebut. 


\section{KESIMPULAN}

Pandemi Covid-19 membuat para pengelola UMKM berbalik arah dan mengharuskan berpikir kreatif agar supaya usaha tetap berjalan terus. Di era transformasi digital ini, semua pelaku usaha harus melek teknologi tak terkecuali pelaku UMKM. Literasi Digital dan Marketing Digital merupakan konsep digital yang saat ini menjadi salah satu konsep populer yang ramai diperbincangkan. Meningkatkan ilmu pengetahuan dan perkembangan teknologi informasi khusus internet semakin menaik pesat, terutama peranan dalam bidang komunikasi dan penyebaran informasi. Kemajuan teknologi informasi dan komunikasi berefek pada kemudahan dan kecepatan dalam perluasan suatu informasi yang salah satu contohnya melalui media internet (Ayuningtyas, Yuliani Indrianingsih, \& Uyuunul Mauidzoh, 2020).

Digitalisasi sendiri telah menjadi bagian keseharian kita saat ini. Realita bahwa masyarakat dari berbagai kalangan usia, gender, kelas sosial, ekonomi dan budaya dapat berhubungan satu sama lain tanpa dibatasi oleh ruang dan waktu dan melonjaknya pengguna smartphone, telah mengubah perilaku konsumen saat ini merupakan kegiatan melakukan promosi brand atau produk melalui media digital (Normawati et al., 2020). Cara ini dianggap paling efektif untuk saat ini sebagai salah satu cara pemasaran bagi semua jenis usaha, tidak terkecuali untuk UMKM. Pelaku UMKM di Kecamatan Semampir berusaha untuk bertransformasi digital dalam upaya mengembangkan usahanya. Para pelaku UMKM membuat flyer yang menarik tentang produknya untuk disebarkan kepada berbagai media sosial bisnis agar dapat diketahui oleh khalayak luas. Amondeys Cake dan Adirasa Cake telah berupaya mengembangkan dirinya melalui marketing Online ini. Namun UMKM minuman masih perlu upaya kreativitas untuk menghasilkan produk yang unik dan menarik.

\section{UCAPAN TERIMA KASIH}

Penulis mengucapkan terima kasih kepada Lambaga Pengabdian dan Penelitian Sekolah Tinggi Ilmu Ekonomi Indonesia (STIESIA) Surabaya yang telah memberi dukungan financial terhadap pengabdian ini.

\section{DAFTAR PUSTAKA}

Amri, A. (2020). Pengaruh Periklanan Melalui Media Sosial Terhadap UMKM di Indonesia di Masa PAndemi. Jurnal Brand, 2(1), 123-130. Retrieved from https://www.academia.edu/42672824/Dampak_Covid-19_Terhadap_UMKM_di_Indonesia

Arifudin, O., Damayanti Rusmana, F., Tanjung, R., \& Wahrudin, U. (2020). Inovasi Kemasan Dan Perluasan Pemasaran Dodol Nanas Di Subang Jawa Barat. Dinamisia : Jurnal Pengabdian Kepada Masyarakat, 4(3), 408-417. https://doi.org/10.31849/dinamisia.v4i3.4469

Atsar, A., \& Fadlian, A. (2021). Sosialisasi Kegiatan Penyuluhan Umkm Mewujudkan Perekonomian Masyarakat Yang Mempunyai Potensi Dan Peran Strategis Menurut UndangUndang No. 20 Tahun 2008. Dinamisia : Jurnal Pengabdian Kepada Masyarakat, 5(5), 12021210. https://doi.org/10.31849/dinamisia.v5i5.4142

Ayuningtyas, A., Yuliani Indrianingsih, \& Uyuunul Mauidzoh. (2020). Pengenalan, Optimalisasi Optimalisasi Pengenalan Produk Unggulan Desa Melalui Pelatihan Website Promosi Kecamatan Patuk Gunungkidul. Dinamisia: Jurnal Pengabdian Kepada Masyarakat, 4(3), 490-495. https://doi.org/10.31849/dinamisia.v4i3.3782

Costaner, L., Guntoro, \& Lisnawita. (2021). Pelatihan Keterampilan Membuat Informasi Berbasis Video Digital Pada Ikatan Remaja Masjid. Dinamisia: Jurnal Pengabdian Kepada Masyarakat, 5(4), 843-849. https://doi.org/10.31849/dinamisia.v5i4.7253

Fitriati, D., Hidayah, N. Y., \& Maspiyanti, F. (2021). Membangun Masyarakat Mandiri dimasa Pandemi COVID-19 Melalui Pelatihan Akutansi Biaya Produk dan Teknik Pemasaran Digital. 
Dinamisia: Jurnal Pengabdian Kepada Masyarakat, 5(4), 911-920. https://doi.org/10.31849/dinamisia.v5i4.5544

Hardilawati, W. laura. (2020). Strategi Bertahan UMKM di Tengah Pandemi Covid-19. Jurnal Akuntansi Dan Ekonomika, 10(1), 89-98. https://doi.org/10.37859/jae.v10i1.1934

Ismail, I., Ulat, M. A., Gunaisah, E., Muhfizar, M., \& Poltak, H. (2021). Pelatihan Teknologi Sistem Informasi bagi Nelayan pada Masa Covid-19 di Era Digital. Dinamisia : Jurnal Pengabdian Kepada Masyarakat, 5(3), 566-574. https://doi.org/10.31849/dinamisia.v5i3.4487

Normawati, R. A., Ike Wardani, S., \& Widayani, A. (2020). Pemanfaatan Digital Marketing sebagai Sarana Komersialisasi Produk Kampung Batik Kembang Turi Blitar. Dinamisia: Jurnal Pengabdian Kepada Masyarakat, 5(1), 253-261. https://doi.org/10.31849/dinamisia.v5i2.4157

Rahman, T., \& Nurdian, Y. (2021). Pendampingan Pemanfaatan Teknologi Digital Untuk Meningkatkan Pemasaran Toko Roti Di Pabian Sumenep. Dinamisia: Jurnal Pengabdian Kepada Masyarakat, 5(3), 645-650. https://doi.org/10.31849/dinamisia.v5i3.4727

Soetjipto, N. (2020). Ketahanan UMKM Jawa Timur Melintasi Pandemi COVID-19. In Uki (Ed.), Penerbit K-Media (2020th ed.). Yogyakarta: K-Media.

Thaha, A. F. (2020). Dampak Covid-19 Terhadap UMKM di Indonesia. Jurnal Brand, 2(1), 147153. Retrieved from https://ejournals.umma.ac.id/index.php/brand

Wiguna, R. I., Menap, Asmawariza, L. H., Husen, L. M. S., Pa'ni, D. M. K., Yulisutomo, S., \& Apriani, L. A. (2021). Pemberdayaan Siswa Melalui Penerapan Program Health Promotion Model Sebagai Upaya Pencegahan Covid-19. Dinamisia: Jurnal Pengabdian Kepada Masyarakat, 5(4), 879-886. https://doi.org/10.31849/dinamisia.v5i4.7176 